\title{
Kinerja Bidan dalam Memberikan Pelayanan Antenatal Care dan Faktor yang Mempengaruhi
}

\author{
Widyawati \\ Program Studi Ilmu Kesehatan Masyarakat Universitas Sari Mutiara Indonesia \\ Jl. Kapten Muslim No 79, Medan 20123 \\ Email : dedi_putra@yahoo.com
}

\begin{abstract}
Abstrak
Angka kematian merupakan barometer status kesehatan, terutama kematian ibu dan kematian bayi. Tingginya angka kematian menunjukkan hasil pencapaian program pembangunan kesehatan di Indonesia. Bidan sebagai ujung tombak dari pembangunan kesehatan yang berhubungan langsung dengan pelayanan kesehatan masyarakat dapat menjadi faktor pendukung atau pendorong namun juga dapat menjadi faktor penghambat. Penelitian ini bertujuan untuk mengetahui pengaruh faktor pengetahuan, keterampilan, motivasi dan kepemimpinan terhadap kinerja bidan dalam memberikan pelayaan antenatal care di Puskesmas Deleng Pokhisen dan Puskesmas Mamas Kabupaten Aceh Tenggara. Metode penelitian yang digunakan adalah observasi analitik dengan rancangan cross sectional dengan jumlah sampel 59 orang. Terdapat 52 responden memiliki pengetahuan baik 98,1\% memiliki kinerja baik. Hasil uji chi square diperoleh nilai $p=0,023$, keterampilan nilai $p=0,026$, motivasi nilai $p=0,031$, dan kepemimpinan nilai $p$ $=0,020$. Sehingga dapat disimpulkan terdapat pengaruh yang signifikan antara pengetahuan, keterampilan, motivasi dan kepemimpinan terhadap kinerja bidan dalam memberikan pelayanan antenatal care di Puskesmas Deleng Pokhisen dan Puskesmas Mamas Kabupaten Aceh Tenggara. Disarankan kepada Dinas Kesehatan, untuk meningkatkan pengetahuan bidan dengan memberikan pelatihan secara berkesinambungan, dan memberikan penyuluhan dan pembentukan kelas ibu hamil, pembinaan keluarga dengan komunikasi, informasi dan edukasi, sehingga $A K I$ dan $A K B$ menurun.
\end{abstract}

Kata kunci : Antenatal Care, Determinan, Kinerja Bidan.

\begin{abstract}
The mortality rate is a barometer of health status, especially maternal mortality and infant mortality. The high mortality rate shows the achievement of health development programs in Indonesia. Midwives as the spearhead of health development that is directly related to public health services can be a supporting factor or a driver but may also be an inhibiting factor. This study aims to determine the effect of knowledge, skills, motivation and leadership factors on the performance of midwives in providing antenatal care at Delip Pokhisen Health Center and Mamas Health Center of Southeast Aceh Regency. The research method used is analytical observation with cross sectional design with sample number 59 people. There are 52 respondents have good knowledge $98,1 \%$ have good performance. Chi square test results obtained $p$ value $=$ 0,023 , skill value $p=0,026$, motivation value $p=0,03 \mathrm{I}$, and leadership value $p=0,020$. So it can be concluded there is a significant influence between knowledge, skills, motivation and leadership on the performance of midwives in providing antenatal care services at Puskesmas Deleng Pokhisen and Puskesmas Mamas Kabupaten Aceh Tenggara. It is suggested to Dinas Kesehatan, to improve midwives knowledge by providing continuous training, and giving counseling and formation of pregnant mother class, family coaching with communication, information and education, so AKI and IMR decrease.
\end{abstract}

Keywords : Antenatal Care, Determinant, Midwife Performance. 


\section{Pendahuluan}

Program Indonesia Sehat merupakan salah satu program dari agenda ke-5 Nawa Cita, yaitu Meningkatkan Kualitas Hidup Manusia Indonesia. Sasaran dari Program Indonesia Sehat adalah meningkatnya derajat kesehatan dan status gizi masyarakat melalui upaya kesehatan dan pemberdayaan masyarakat yang didukung dengan perlindungan finansial dan pemerataan pelayanan kesehatan. Angka kematian merupakan barometer status kesehatan, terutama kematian ibu dan kematian bayi. Tingginya angka kematian tersebut menunjukkan hasil pencapaian program pembangunan kesehatan di Indonesia. Angka Kematian Ibu (AKI) di Indonesia pada tahun 2015 sebesar 359/100.000 KH dan Angka Kematian bayi (AKB) adalah 32/1.000 KH. Dan sesuai dengan Rencana Strategis Kemenkes tahun 2015-2019 pada tahun 2019 ditargetkan AKI akan menurun menjadi 306/100.000 KH sedangkan AKB akan menurun menjadi 24/1.000 KH. Di provinsi Aceh AKI pada tahun 2015 adalah 134/100.000 KH dan AKB sebesar $12 / 1.000 \mathrm{KH}$, dimana penyebabnya adalah kematian ibu dalam keadaan hamil sebanyak (23\%). Dan AKI di Kabupaten Aceh Tenggara sebanyak 1/100.000 KH sedangkan AKB sebanyak 5/1.000 KH. ${ }^{2}$

Upaya percepatan penurunan AKI dapat dilakukan dengan menjamin agar setiap ibu mampu mengakses pelayanan kesehatan ibu yang berkualitas, seperti pelayanan kesehatan ibu hamil, pertolongan persalinan oleh tenaga kesehatan terlatih di fasilitas pelayanan kesehatan, perawatan pasca persalinan bagi ibu dan bayi, perawatan khusus dan rujukan jika terjadi komplikasi dan pelayanan keluarga berencana. Pelayanan kesehatan ibu hamil diberikan kepada ibu hamil yang dilakukan oleh tenaga kesehatan di fasilitas pelayanan kesehatan. Proses ini dilakukan selama rentang usia kehamilan ibu yang dikelompokkan sesuai usia kehamilan menjadi trimester pertama, trimester kedua, dan trimester ketiga.
Pelayanan kesehatan ibu hamil yang diberikan harus memenuhi elemen pelayanan sebagai berikut: penimbangan berat badan dan pengukuran tinggi badan, pengukuran tekanan darah, pengukuran Lingkar Lengan Atas (LILA), pengukuran tinggi puncak rahim (fundus uteri), penentuan status imunisasi tetanus dan pemberian imunisasi tetanus toksoid sesuai status imunisasi, pemberian tablet tambah darah minimal 90 tablet selama kehamilan, penentuan presentasi janin dan denyut jantung janin (DJJ), pelaksanaan temu wicara (pemberian konseling, termasuk keluarga berencana), pelayanan tes laboratorium sederhana, minimal tes hemoglobin darah (HB), pemeriksaan protein urin dan pemeriksaan golongan darah (bila belum pernah dilakukan sebelumnya); dan tatalaksana kasus. ${ }^{5}$

Selain elemen tindakan yang harus dipenuhi, pelayanan kesehatan ibu hamil juga harus memenuhi frekuensi minimal di tiap trimester, yaitu satu kali pada trimester pertama (usia kehamilan 0-12 minggu), satu kali pada trimester kedua (usia kehamilan 12-24 minggu), dan dua kali pada trimester ketiga (usia kehamilan 24 minggu sampai persalinan). Standar waktu pelayanan tersebut dianjurkan untuk menjamin perlindungan terhadap ibu hamil dan atau janin berupa deteksi dini faktor risiko, pencegahan, dan penanganan dini komplikasi kehamilan. Berdasarkan hal tersebut maka peran bidan sebagai ujung tombak pelayanan kesehatan ibu dan anak harus mampu dan terampil dalam memberikan pelayanan sesuai dengan standar yang ditetapkan. Penilaian terhadap pelaksanaan pelayanan kesehatan ibu hamil dapat dilakukan dengan melihat cakupan K1 dan K4. Cakupan K1 adalah jumlah ibu hamil yang telah memperoleh pelayanan antenatal pertama kali oleh tenaga kesehatan, sedangkan cakupan K4 adalah jumlah ibu hamil yang telah memperoleh pelayanan antenatal sesuai dengan standar paling sedikit empat kali sesuai jadwal yang dianjurkan. Di Indonesia tahun 2015 cakupan K4 sebesar 
$(87,48 \%)$ dan di Provinsi Aceh cakupan K4 sebesar $(75,67 \%)^{3}$

\section{Metode}

Jenis penelitian adalah explanatory research dengan pendekatan cross sectional, menggunakan kuesioner terstruktur melalui wawancara serta observasi. Populasi dalam penelitian ini adalah semua Bidan PNS yang bekerja di Puskesmas Deleng Pokhisen sebanyak 30 orang dan di Puskesmas Mamas sebanyak 29 orang, dengan total keseluruhan adalah 59 orang. Pengambilan sampel menggunakan total populasi.

Analisis data dilakukan secara univariat, bivariate dan multivariate. Analisis bivariat dilakukan dengan menggambarkan distribusi frekuensi dari setiap variabel yang diteliti. Analisis bivariate dilakukan dengan uji Chi Square yang bertujuan mengetahui hubungan setiap variabel independen yaitu pengetahuan, keterampilan, motivasi, dan kepemimpinan dengankinerja bidan. Setiap variabel dengan nilai $\mathrm{Pv} \quad ₫ 0,05$ maka dinyatakan memiliki hubungan yang signifikan. sedangkan untuk mengetahui variabel yang mempunyai pengaruh terbesar terhadap variabel kinerja dilakukan analisis multivariate dengan menggunakan uji Regresi Logistik Berganda.
Hasil

Tabel 1. Karakteristik Responden

\begin{tabular}{llll}
\hline Variabel & Kategori & n & \% \\
\hline Umur & $23-34$ th & 48 & 81,4 \\
Pendidikan & $35-46$ th & 11 & 18,6 \\
& D3 & 54 & 91,5 \\
Lama kerja & S1 & 5 & 8,5 \\
& 8-14 th & 43 & 72,9 \\
& & 16 & 27,1 \\
\hline
\end{tabular}

Karakteristik responden mayoritas berada pada kategori umur 21 - 35 tahun yaitu sebanyak $48(81,4 \%)$ dan umur 36 45 tahun sebanyak $11(18,6 \%)$. Pendidikan Terakhir. Dan tingkat pendidikan responden sebagian besar berpendidikan Diploma III yaitu sebanyak 54 (91,5\%), dan berpendidikan Sarjana (S1) sebanyak 5 $(8,5 \%)$. Sedangkan lama responden bekerja rata-rata $2-5$ tahun sebanyak $35(59,3 \%)$, sudah bekerja > 5 tahun sebanyak 16 $(27,1 \%)$, dan masih bekerja $<2$ tahun sebanyak 8 (13,6\%) (Tabel 1).

Berdasarkan hasil analisis bivariate diketahui bahwa ada pengaruh yang signifikan antara faktor pengetahuan $(\mathrm{Pv}=0,023)$, keterampilan, motivasi, dan kepemimpinan dengan kinerja bidan dalam pelayanan antenatal care di Puskesmas Deleng Pokhisen dan Puskesmas Mamas Kabupaten Aceh Tenggara.

Tabel 2. Hubungan Pengetahuan, Keterampilan, Motivasi, dan Kepemimpinan dengan Kinerja Bidan dalam Memberikan Pelayanan Antenatal Care

\begin{tabular}{|c|c|c|c|c|c|c|}
\hline \multirow{3}{*}{ Variabel } & \multirow{3}{*}{ Kategori } & \multicolumn{4}{|c|}{ Kinerja Bidan dalam Pelayanan Antenatal Care } & \multirow{3}{*}{$\mathbf{P v}$} \\
\hline & & \multicolumn{2}{|c|}{ Kinerja baik } & \multicolumn{2}{|c|}{ Kinerja tidak baik } & \\
\hline & & $\mathbf{n}$ & $\%$ & $\mathbf{n}$ & $\%$ & \\
\hline \multirow{2}{*}{ Pengetahuan } & Baik & 51 & 98,1 & 1 & 1,9 & 0,023 \\
\hline & Kurang & 3 & 42,8 & 4 & 57,2 & \\
\hline \multirow[t]{2}{*}{ Keterampilan } & Keterampilan baik & 43 & 100,0 & 0 & 0 & 0,023 \\
\hline & Keterampilan kurang & 11 & 68,7 & 5 & 31,3 & \\
\hline \multirow[t]{2}{*}{ Motivasi } & Motivasi baik & 41 & 97,6 & 1 & 2,2 & 0,031 \\
\hline & Motivasi kurang & 13 & 76,5 & 4 & 23,5 & \\
\hline \multirow[t]{2}{*}{ Kepemimpinan } & Kepemimpinan baik & 36 & 94,7 & 2 & 5,3 & 0,023 \\
\hline & Kepemimpinan kurang & 18 & 85,7 & 3 & 14,3 & \\
\hline
\end{tabular}


Tabel 3. Uji Regresi Logistik Berganda

\begin{tabular}{lcc}
\hline Variabel & OR & P value \\
\hline Pengetahuan & $3,227^{*}$ & 0,011 \\
Keterampilan & 2,689 & 0,015 \\
Motivasi & 1,179 & 0,023 \\
Kepemimpinan & 1,754 & 0,020 \\
\hline Constant & $-7,536$ & 0,000 \\
\hline
\end{tabular}

Berdasarkan hasil analisis multivariat diketahui bahwa faktor yang paling dominan mempengaruhi kinerja bidan dalam memberikan pelayanan antenatal care di Puskesmas Deleng Pokhisen dan Puskesmas Mamas Kabupaten Aceh Tenggara adalah faktor pengetahuan. Pengetahuan merupakan kemampuan intelektual dan tingkat pemahaman bidan terutama kompetensi bidan terhadap penerapan standar pelayanan ANC sesuai pendidikan kebidanan.

Hasil analisis multivariate ini berarti juga bahwa jika ingin meningkatkan kinerja maka faktor pengetahuan secara keahlian akan memberikan keterampilan yang baik secara teknis sehingga dapat melakukan pelayanan antenatal sesuai dengan standar, juga mampu melakukan pencatatan dan pelaporan terkait pekerjaan yang dilakukan sebagai bagian dari standar prosedur kerja, dengan pencatatan dan pelaporan yang baik diketahui masalah yang dihadapi oleh bidan dalam pelayanan antenatal. Fator motivasi dan kepemimpinan menjadi fator pendorong bagi bidan dalam memberikan pelayanan antenatal care sesuai standar.

\section{Pembahasan}

Pada penelitian ini variabel pengetahuan diperoleh nilai $p=0,023$, disimpulkan ada hubungan yang signifikan antara pengetahuan dengan kinerja bidan dalam memberikan pelayanan antenatal care di Puskesmas Deleng Pokhisen dan Puskesmas Mamas Kabupaten Aceh Tenggara tahun 2017. Analisis kinerja bidan pada pelayanan antenatal care di Puskesmas Sekabupaten Gowa dan hasil uji statistik dengan Chi Square diperoleh nilai $p=0,04$ lebih kecil dari $\alpha=0,05$, yang berarti Ho ditolak, dengan demikian terdapat hubungan antara pengetahuan dengan kinerja bidan terhadap ANC di Puskesmas Sekabupaten Gowa. ${ }^{12}$

Ditemukan dari 19 responden yang berpengetahuan baik sebagian besar memiliki kinerja baik yaitu 17 orang $(89,5 \%)$, dari 7 orang yang bepengetahuan cukup sebagian besar memiliki kinerja dengan katagori cukup yaitu 5 orang $(71,5 \%)$, dari 6 orang yang berpengetahuan kurang sebagian besar memiliki kinerja dengan katagori cukup yaitu 5 orang $(83,5 \%)$. Selanjutnya dianalisa statistik dengan tingkat kemaknaan adalah 95\% (p. value < 0,05) dan nilai Probabilitas (P) $0,01{ }^{7}$ Sehingga dapat diambil kesimpulan, bahwa ada hubungan antara kinerja bidan dengan pengetahuan. Pengetahuan merupakan hal yang sangat penting dalam pelayanan antenatal care yang diberikan oleh bidan dapat mempengaruhi kunjungan antenatal care karena dengan pengetahuan yang baik bidan mampu memberikan kepuasan kepada pasien, dengan demikian pasien akan kembali untuk melakukan kunjungan ulang yang meliputi kunjungan K1 sampai K4. ${ }^{11}$

Tingkat kinerja bidan dalam memberikan pelayanan antenatal care dapat dihubungkan dengan berbagai faktor yang ada di sekitarnya. Faktor yang berhubungan dengan kinerja yaitu variabel individu, psikologis dan organisasi. Faktor individu yang berhubungan dengan kinerja adalah pengetahuan, masa kerja, keterampilan, tingkat sosial, keluarga, dan demografis. Faktor psikologis yang berhubungan dengan kinerja bidan adalah persepsi terhadap imbalan, motivasi kerja, sikap, kepribadian, dan belajar. Faktor organisasi yang berhubungan dengan dengan kinerja bidan adalah sumber daya, kepemimpinan, penghargaan, struktur, desain pekerjaan, fasilitas kerja, dan iklim organisasi.

Pada penelitian ini didapatkan sebagian besar bidan mempunyai pengetahuan yang baik tentang pelayanan antenatal care dan menunjukkan kinerja 
yang baik pula dalam pelayanannya. Pengetahuan merupakan kemampuan intelektual dan tingkat pemahaman bidan terutama kompetensi bidan dalam memberikan pelayanan antenatal care sesuai pendidikan kebidanan yang diperlukan untuk melaksanakan fungsi umumnya sebagai bidan, meliputi: deteksi dini, pengobatan atau rujukan dari komplikasi tertentu dan fungsi khususnya sebagai manajer, pendidik dan peneliti. Pengetahuan sangat erat hubungannya dengan pendidikan bahwa seseorang dengan pendidikan tinggi semakin luas pengetahuannaya, dalam hal ini responden mayoritas berpendidikan Diploma III sebanyak (91,5\%), berpendidikan S1 sebanyak $(8,5 \%)$.

Pengetahuan merupakan faktor yang mempengaruhi seseorang untuk berperilaku positif dan menghasilkan output yang baik. Semakin baik pengetahuan bidan tentang pelayanan antenatal care maka akan lebih semangat dan baik kaulitas kerjanya dalam melaksanakan tugas. Jika pengetahuan bidan baik maka akan merasa senang berbagi ilmu dan menolong orang yang membutuhkan sesuai sumpah yang diucapkan sebagai seorang bidan. Akan tetapi jika pengetahuan kurang maka yang bersangkutan akan malas, takut untuk melayani pasien karena khawatir dengan pertanyaan-pertanyaan yang muncul dari pasien dan keluarga, petugas seperti ini juga tidak bisa memberikan rasa puas pada pasien dan pada diri sendiri. Fenomena di lapangan ditemukan mayoritas bidan berpengetahuan baik tentang asuhan kebidanan pada ibu hamil. Tetapi ada beberapa item pertanyaan yang bidan lebih banyak menjawab salah yaitu pertanyaan tentang pentingnya mengukur tinggi badan ibu hamil, bidan banyak yang tidak mengetahui manfaat pengukuran TB yaitu untuk melihat faktor risiko ibu terindikasi panggul sempit yang berakibat ibu hamil kemungkinan sulit untuk melahirkan normal.
Bidan juga susah untuk menjawab berapa kenaikan BB yang diharapkan untuk ibu hamil setiap bulan sejak usia kehamilan 4 bulan dan bidan tidak mengetahui fungsi pengukuran tinggi rahim untuk melihat pertumbuhan janin apakah sesuai dengan usia kehamilan. Untuk itu upaya yang harus dilakukan adalah tetap harus meningkatkan mutu pelayanan kebidanan sehingga dapat memberikan antenatal care yang bermutu tinggi untuk mengoptimalkan kesehatan selama kehamilan. Peran bidan dalam peningkatan mutu pelayanan kebidanan yaitu bidan harus mengakui bahwa mereka ada di posisi utama untuk menganjurkan dan memelihara kualitas dan ini dapat dilakukan melalui kerja sama yang baik dengan bidan koordinator, pimpinan puskesmas, sesama bidan, dan tenaga kesehatan lainnya.

Bidan membuat laporan kasus dan mendiskusikannya dengan tim, bidan harus menyetujui bahwa kualitas adalah persoalan yang akan menyatukan mereka dengan profesional lain, dan bidan harus belajar mengerti dan bekerja untuk menghasilkan kualitas dan sasaran menuju masa yang akan datang. Semua hal ini dapat dicapai dengan merencanakan perkembangan karir bidan melalui pendidikan berkelanjutan dengan mengikuti seminar atau lokakarya, dan melanjutkan pendidikan ke jenjang yang lebih tinggi.

Keterampilan adalah kemampuan secara teknis atau praktik dalam suatu bidang pekerjaan. Analisis faktor faktor yang berpengaruh terhadap kinerja bidan desa pada pelayanan antenatal care dalam program jaminan kesehatan daerah di Kabupaten Kapuas Kalimantan Tengah, hasil penelitian menunjukkan dengan uji $\mathrm{t}$ besarnya pengaruh keterampilan (skill) terhadap kinerja bidan desa positif sebesar $19,2 \%$ adalah signifikan artinya benarbenar berpengaruh karena sig $=0,031 .{ }^{8}$

Pemahaman tentang ketrampilan dalam bekerja merupakan suatu totalitas diri pekerja baik secara fisik maupun 
mental dalam menghadapi pekerjaannya. Keterampilan fisik didapatkan dari belajar dengan meningkatkan skill dalam bekerja. Sedangkan pemahaman mental diartikan sebagai kemampuan berfikir pekerjaan kearah bagaimana seseorang secara matang dalam menghadapi pekerjaan yang ada.

Keterampilan bidan adalah sebagai keberadaan dari pengetahuan, pemahaman, masalah yang timbul dan keterampilan untuk memecahkan masalah tentang antenatal care. Pada penelitian ini didapatkan seluruh bidan yang mempunyai keterampilan baik mempunyai kinerja yang baik juga dalam memberikan pelayanan antenatal care yaitu sebesar $72,9 \%$. Puskesmas Deleng Pokhisen dan Puskesmas Mamas sudah mepunyai SOP tentang asuhan pelayanan pada ibu hamil, dan semua bidan sudah melakukan pemeriksaan sesuai SOP dan mengikuti tahapan dalam pemeriksaan antenatal care, hanya saja bidan tidak menanyakan secara terperinci sesuai item pertanyaan yang ada di format kuesioner. Pemeriksaan ANC yang dilakukan bidan di lapangan berpatokan pada SOP yang ada di puskesmas dan disesuaikan dengan format pemeriksaan ibu hamil yang ada di buku KIA.

Uraian SOP pelaksanaan pemeriksaan ibu hamil di Puskesmas Deleng Pokhisen dan Puskesmas Mamas adalah: 1) Lakukan anamnesa meliputi: tanyakan HPHT ibu dan tentukan hari taksiran partus (HTP), ukur LILA dan TB ibu, tanyakan riwayat penggunaan alat kontrasepsi, tanyakan riwayat penyakit dan keluhan saat ini, tanyakan jumlah anak dan jumlah persalinan (GPA), tanyakan riwayat kehamilan, tanyakan riwayat persalinan, tanyakan status perkawinan, status imunisasi; 2) Cuci tangan; 3) Beritahu ibu bahwa akan dilakukan pemeriksaan kehamilan sesuai dengan maneuver leopold dan pemeriksaan lainnya; 4) Gunakan sarung tangan; 5) Posisikan ibu dalam keadaan supine. Lakukan pemeriksaan head to toe meliputi: a) Pemeriksaan kepala leher: kepala, mata, hidung, mulut, telinga, leher; b) Dada: jantung, paru, payudara, pengeluaran ASI, c) Abdomen: uterus (palpasi kontraksi, leopold I, leopold II, leopold III, leopold IV), pigmentasi, perineum dan genital; d) Ekstremitas atas dan ekstremitas bawah; e) Eliminasi: BAK dan BAB. 6) Melakukan pemeriksaan protein urine; 7) Mencuci tangan; 8) Lakukan konseling HIV; 9) Mengirim ibu ke laboratorium untuk pemeriksaan golongan darah; 10) Menyampaikan hasil pemeriksaan ANC pada ibu serta hasil laboratorium; 11) Merencanakan kunjungan ulang; dan 12) Melakukan pencatatan dan pelaporan pada register dan buku KIA.

Faktor lain yang menyebabkan kinerja kurang adalah ketersediaan alat dan perlengkapan untuk pemeriksaan kehamilan sesuai standar. Penyediaan sarana dan alat kerja langsung mempengaruhi kinerja setiap orang, penggunaan peralatan dan teknologi maju sekarang ini bukan saja dimaksudkan untuk meningkatkan kinerja, akan tetapi juga dipandang untuk memberikan kemudahan dan kenyamanan kerja. Perlengkapan alat untuk tindakan antenatal care yang ada di lapangan (Puskesmas Deleng Pokhisen dan Puskesmas Mamas) adalah buku KIA dan register, alat tulis, spigmomanometer, stetoskop, timbangan, meteran, LILA, doppler, sarung tangan, jam, kasa, jelly dan obat SF, Kalcium, vitamin C, vitamin B complek. Sedangkan alat yang tidak ada untuk melakukan tindakan ANC sesuai kuesioner adalah jangka panggul untuk mengukur panggul ibu, thermometer untuk mengukur vital sing, reflek patella untuk memeriksa ekstremitas, dan perlengkapan laboratorium. Item pertanyaan yang paling sering tidak dilakukan bidan adalah: tidak menanyakan secara lengkap tentang riwayat menstruasi, riwayat keluarga, riwayat psikososial spiritual, tidak mengukur TB, lingkar lengan atas, pengukuran panggul, melakukan pemeriksaan genitalia, dan kurang 
keterampilan dalam membuat dokumentasi asuhan kebidanan.

Adapun penyebab bidan tidak menanyakan kuesioner secara lengkap adalah karena item pertanyaan tersebut tidak ada di dalam SOP antenatal care yang ada di puskesmas, alasan lain adalah menurut bidan pertanyaan seperti riwayat menstruasi, riwayat keluarga dan riwayat psiko sosial spritual tidak dianggap masalah jika kehamilan ibu normal, dan jika ada masalah dengan kehamilan atau ibu ada indikasi untuk dirujuk maka bidan akan menanyakan secara lengkap sesuai SOP. Pengukuran panggul tidak dilakukan karena alat jangka panggul tidak tersedia dan item tersebut tidak ada di SOP, sedangkan pengukuran tinggi badan alat ada tetapi bidan tidak melakukan pengukuran TB ibu dengan alasan tindakan tersebut tidak begitu diperlukan. Seharusnya pertanyaan yang tidak ada di buku KIA ditanyakan juga kepada ibu, jika tidak ada masalah dengan kesehatan ibu tidak perlu didokumentasikan akan tetapi jika ada masalah maka petugas langsung bisa mendokumentasikan di kolom catatan.

Puskesmas Deleng Pokhisen dan Puskesmas Mamas adalah Puskemas tertinggi capaian $\mathrm{K} 1$ dan $\mathrm{K} 4$, sedangkan capaian K1 dan K4 terendah adalah Puskesmas Naga Timbul. Tingginya cakupan kunjungan K1 dan K4 karena ibu hamil di wilayah kerjanya (Puskesmas Deleng Pokhisen dan Puskesmas Mamas) merasa puas dengan pelyanan yang diberikan bidan dan puskesmas tersebut mempunyai jarak tempuh yang lebih dekat dengan desa-desa di wilayahnya. Rasa puas yang ditunjukkan klien merupakan wujud mutu pelayanan kebidanan pada tingkat kesempurnaan pelayanan. Kepuasan dan kepercayaan pasien terhadap Puskesmas Deleng Pokhisen dan Puskesmas Mamas memegang peranan penting dalam melaksanakan fungsinya sebagai pusat pelayanan kesehatan strata pertama, karena pasien sebagai pelanggan merupakan alat promosi yang paling efektif dan akurat untuk menarik perhatian pelanggan lainnya dengan cara memberi informasi kepada orang lain.

Di lapangan yaitu di Puskesmas Deleng Pokhisen dan Puskesmas Mamas selain keterampilan bidan dalam kategori baik ada beberapa faktor yang mempengaruhi dalam memberikan kepuasan kepada ibu hamil yaitu: 1) Pengetahuan ibu hamil tentang jenis pelayanan yang akan diterima yaitu antenatal care, hal ini tercapai karena kegiatan penyuluhan secara berkesinambungan yang dilakukan puskesmas dan pembentukan kelas ibu hamil; 2) Empati yang ditunjukkan dari bidan; 3) Biaya pelayanan kesehatan grátis; 4) Penampilan fisik (kerapian) petugas, kondisi kebersihan dan kenyamanan ruangan. Semua hal ini dapat tercapai karena semua bidan minimal berpendidikan Diploma III. Puskesmas juga mengikutkan petugas jika ada undangan pelatihan, dimana pelatihan adalah satu cara untuk mengembangkan sumber daya manusia yang bertujuan untuk meningkatkan kemampuan dan keterampilan seseorang. Dan peraturan pemerintah yang mengikat profesi untuk mendapatkan STR menjadikan individu harus mampu memberikan pelayanan dengan baik sesuai kompetensinya.

Kinerja bidan pada pelayanan antenatal care (ANC) di wilayah kerja Puskesmas Aek Songsongan Kecamatan Bandar Pulau Kabupaten Asahan menyimpulkan bahwa variabel yang mempunyai pengaruh signifikan terhadap kinerja adalah variabel pengetahuan dengan $\mathrm{p}=0,002$, variabel sarana $\mathrm{p}=$ 0,001 dan variabel motivasi $\mathrm{p}=0,0001$, sedangkan variabel yang tidak berpengaruh terhadap kinerja bidan adalah variabel umur umur $\mathrm{p}=0,312$, pendidikan $\mathrm{p}=$ 0,416 , masa kerja $\mathrm{p}=0,461$ dan imbalan $\mathrm{p}$ $=0,49 .^{10}$

Motivasi adalah rangsangan dari luar dalam bentuk benda atau bukan benda yang dapat menumbuhkan dorongan pada orang untuk memiliki, menikmati, menguasai, atau mencapai benda/bukan 
benda tersebut. Kesesuaian hasil penelitian ini dengan teori dan penelitian sebelumnya terjadi karena bidan yang memiliki motivasi tinggi akan mendorong bidan untuk bekerja lebih giat. Motivasi dapat muncul karena adanya kebutuhan dalam diri bidan. Kebutuhan ini yang selanjutnya mendorong bidan untuk melakukan sesuatu agar kebutuhan yang harus dipenuhinya tersebut tercapai. Adanya hubungan positif memberi makna bahwa Semakin tinggi motivasi yang dimiliki oleh bidan, maka semakin baik kinerja yang dihasilkan dalam pelayanan. ${ }^{7}$

Peneliti dapat berasumsi bahwa motivasi adalah sebagai pendorong bagi bidan dalam melaksanakan tugas untuk memberikan asuhan pada ibu hamil, disini dapat kita lihat dari kemauan dan kemampuan tinggi beradaptasi dengan masyarakat dan memberikan pelayanan kesehatan sesuai dengan tugas dan fungsinya sehingga dalam pelaksanaan tugas terlaksana secara optimal dan pasien pun mau melakukan kunjungan ulang ke puskesmas tersebut, dan bidan pun semakin termotivasi dalam memberikan pelayanan pemeriksaan ibu hamil kepada pasien sehingga dengan demikian kinerja bidan semain baik dan memuaskan. Keberhasilan cakupan kunjungan K1 dan K4 di Puskesmas Deleng Pokhisen dan Puskesmas Mamas adalah hasil kerja keras dari bidan, dimana tugas profesi sebagai bidan menjadi motivasi, sehingga petugas selalu menyediakan waktu untuk memberikan informasi kepada masyarakat tentang pentingnya pemeriksaan kehamilan. Pemberian informasi tidak selalu di lingkungan puskesmas tetapi juga di lingkungan rumah karena setiap bidan yang bekerja di puskesmas mempunyai peran dan tugas untuk membina masyarakat disekitarnya. Menurut bidan tingginya kunjungan $\mathrm{K} 1$ adalah bidan memberikan pelayanan yang baik kepada ibu tanpa ada biaya. Sedangkan jika ibu melakukan pemeriksaan ke BPS maka ibu akan dikenakan biaya sementara yang memeriksa adalah bidan yang sama.
Kepemimpinan mengandung pengertian mengarahkan, membina atau mengatur, menuntun dan juga menunjukkan ataupun mempengaruhi. Pemimpin mempunyai tanggung jawab baik secara fisik maupun spiritual terhadap keberhasilan aktivitas kerja dari yang dipimpin, sehingga menjadi pemimpin itu tidak mudah dan tidak akan setiap orang mempunyai kesamaan di dalam menjalankan kepemimpinannya. Maka kepemimpinan adalah kegiatan untuk memengaruhi perilaku orang lain, atau seni memengaruhi perilaku manusia baik perorangan maupun kelompok. Kepemimpinan merupakan salah satu faktor yang sangat penting dalam suatu organisai karena sebagian besar keberhasilan dan kegagalan suatu organisasi ditentukan oleh kepemimpinan dalam organisasi tersebut. ${ }^{4}$

Faktor-faktor yang berpengaruh terhadap kinerja bidan dalam pelaksanaan standar asuhan kebidanan antenatal care di puskesmas rawat inap Kabupaten Gresik, hasil penelitian menunjukkan tidak ada hubungan antara kepemimpinan, kreativitas dan pengetahuan dengan kinerja bidan dalam SAK ANC. ${ }^{9}$ Dan penelitian Lamere (2013), di dapat hubungan kepemimpinan dengan kinerja bidan menunjukkan bahwa dari 38 responden yang menyatakan kepemimpinan pemimpin puskesmas cukup baik, sebanyak 8 responden $(21,1 \%)$ memiliki kinerja rendah. Sementara itu, terdapat 11 responden yang menyatakan kepemimpinan pemimpin mereka kurang baik yakni sebanyak 7 responden $(63,6 \%)$ yang memiliki kinerja rendah. Hasil uji statistik dengan Chi - Square diperoleh nilai $\rho=0,007(\rho<0,005)$ yang berarti Ho ditolak dan Ha diterima, dengan demikian ada hubungan kepemimpinan pemimpin dengan kinerja bidan. Hasil uji koefisien $\varphi$ (phi) diperoleh nilai $\mathrm{R} \varphi=0,386$ yang berarti terdapat hubungan rendah antara kepemimpinan pemimpin puskesmas dengan kinerja bidan pada pelayanan ANC di puskesmas sekabupaten gowa. 
Kepemimpinan di puskesmas, pimpinan di puskesmas telah memahami dan mampu melaksanakan tugas pokok dan fungsinya sesuai dengan tata kerja organisasi yang telah ditetapkan. Hal ini tercermin dari kredibilitas, prestasi, dan inovasi yang telah dicapai dalam mengelola penyelenggaraan puskesmas. Selain itu pimpinan juga harus mencerminkan sikap visioner, demokratis, transparan dan inovatif. Sedangkan bidan dalam menjalankan tugasnya bertanggungjawab kepada pimpinannya yaitu Kepala Puskesmas. Maka Kepala Puskesmas juga harus melakukan pembinaan kepada seluruh bidan di wilayah kerjanya. Dalam hal ini diharapkan pimpinan dapat mempengaruhi bidan melalui proses komunikasi yang baik sehingga bidan mengikuti keputusannya, karena seorang pimpinan akan mungkin dianggap efektif dan tidak efektif dari sudut kepuasan bawahannya. Akan tetapi penerimaan pemerintah atau permintaan seorang pemimpin terletak pada harapan para bawahannya dimana tanggapan yang menyenangkan akan menimbulkan hasil yang menarik. Dalam penelitian ini kepemimpinan di kategorikan baik, akan tetapi masih ada bidan yang mempunyai kinerja kurang, ini berkemungkinan karena bidan tersebut termasuk berpengetahuan kurang sehingga sudah merasa cukup dan puas dengan pelayanan yang diberikan. Kemungkinan lain adalah faktor umur dimana responden kategori umur 35 - 46 tahun sebanyak $11(18,6 \%)$ dan mereka merasa sebaya dan merasa kurang puas dengan sistem manajemen yang ditetapkan.

\section{Kesimpulan}

Pengetahuan Sebagian besar bidan mempunyai pengetahuan yang baik tentang pelayanan antenatal care dan menunjukkan kinerja yang baik pula dalam pelayanannya. Maka dapat disimpulkan ada hubungan pengetahuan terhadap kinerja bidan dalam memberikan pelayanan antenatal care. Pada penelitian ini didapatkan seluruh bidan yang mempunyai keterampilan baik mempunyai kinerja yang baik dalam memberikan pelayanan antenatal care. Maka dapat disimpulkan ada hubungan keterampilan terhadap kinerja bidan. Sedangkan motivasi yang tinggi dalam melaksanakan tugas untuk memberikan asuhan pada ibu hamil, dapat dilihat dari kemauan dan kemampuan bidan untuk beradaptasi dengan masyarakat dan memberikan pelayanan kesehatan sesuai dengan tugas dan fungsinya, maka ada hubungan motivasi terhadap kinerja bidan. Kepemimpinan manajerial di puskesmas berarti kemampuan menggerakkan program kesehatan sesuai dengan standar program yang ada, serta menggerakkan SDM untuk melaksanakan standar program tersebut dengan tehnik motivasi, komunikasi dan supervisi yang efektif.

\section{Saran}

$\begin{array}{rlr}\text { Kepada } & \text { Puskesmas untuk } \\ \text { meningkatkan } & \text { pengetahuan } & \text { dan }\end{array}$ keterampilan bidan tentang antenatal care melalui pendidikan berkelanjutan dengan mengikuti seminar atau lokakarya, dan melanjutkan pendidikan ke jenjang yang lebih tinggi sehingga komunikasi dan pelayanan yang diberikan lebih maksimal. Melengkapi alat yang kurang sesuai standar sehingga semua tahapan tindakan untuk ibu hamil bisa dilakukan sesuai 10T dan dapat melakukan pemeriksaan fisik secara head to toe. Bidan juga harus melakukan anamnesis riwayat kesehatan sebelumnya dan riywayat penyakit keturunan dan menjadikan Puskesmas Deleng Pokhisen dan Puskesmas Mamas sebagai contoh untuk puskemas lainnya tentang pelayanan antenatal care di masyarakat.

\section{Daftar Pustaka}

1. Rivai. Manajemen Sumber Daya Manusia untuk Perusahaan. Dari Teori Ke Praktek. Jakarta: PT. Raja Grafindo Persada; 2010.

2. Dinkes Kabupaten Aceh Tenggara. Laporan Bulanan 
3. Kemenkes RI, 2016. Profil Kesehatan Indonesia Tahun 2016: Riskesdas. Jakarta : Balitbang Kemenkes RI; 2017.

4. Miftah T. Kepemimpinan dalam Manajemen. Jakarta: Raja Grafindo Persada; 2010.

5. Kemenkes RI. Riset Kesehatan Dasar : Riskesdas. Jakarta : Balitbang Kemenkes RI; 2013.

6. Notoatmodjo S. Pendidikan dan Perilaku Kesehatan. Jakarta: Rineka Cipta; 2012.

7. Kusmayati L. Jurnal Kesehatan Masyarakat, Faktor-Faktor yang Berhubungan dengan Kinerja bidan dalam Kunjungan K4 pada Ibu Hamil di Puskesmas Syamtalira Bayu Kabupaten Aceh Utara Tahun 2012. diakses tanggal $\quad 10 \quad$ Agustus 2017; http://www.ejournal.uui.ac.id.

8. Dewi AP. Analisis Faktor-Faktor yang Berpengaruh terhadap Kinerja Bidan Desa pada Pelayanan Antenatal Care dalam Program Jaminan Kesehatan Daerah di Kabupaten Kalimantan Tengah. Jurnal Sains Manajemen
Vol. 3, diakses tanggal 2 Agustus 2017; http://www.jsm-msmupr.com.

9. Hamidah S. Faktor-Faktor yang Berpengaruh terhadap Kinerja Bidan dalam Pelaksanaan Standar Asuhan Kebidanan Antenatal Care di Puskesmas Rawat Inap Kabupaten Gresik; 2014. Diakses 25 Juli 2017; http://www.download.portalgaruda.org

10. Simanjuntak. Kinerja Bidan pada Pelayanan Antenatal Care (ANC) di Wilayah Kerja Puskesmas Aek Songsongan Kecamatan Bandar Pulau Kabupaten Asahan; 2016. Diakses 25 Juli 2017; http://www.usu.ac.id/pdf.

11. Konthjoro. Pelayanan Antenatal oleh Bidan; 2010. Diakses tanggal 8 Agustus 2017; http://www.infobidannia.wordpress.com.

12. Lamere L. Analisis Kinerja Bidan pada Pelayanan Antenatal Care di Puskesmas Sekabupaten Gowa; 2013. Diakses tanggal 2 Agustus 2017; http://www.repository.unhas.ac.id. 